\title{
Role of dietary fat type in the development of adiposity from dietary obesity-susceptible Sprague-Dawley rats
}

\author{
In Surk Jang ${ }^{1 *}$, Dae Yeon Hwang ${ }^{2}$, Kab Ryong Chae ${ }^{2}$, Ju Eun Lee ${ }^{2}$, Yong Kyu Kim², \\ Tae Seok Kang ${ }^{2}$, Jin Hee Hwang ${ }^{2}$, Chae Hyung Lim², Young Bum Huh ${ }^{3}$ and Jung Sik Cho ${ }^{2}$ \\ ${ }^{1}$ Department of Animal Science \& Biotechnology, RAIRC, \\ Jinju National University, Chilam-Dong 150, Jinju, KyeongNam, Korea \\ ${ }^{2}$ Laboratory Animal Resources, National Institute of Toxicological Research, \\ Korea FDA, Nokbun-Dong, Eungpyung-Ku 5, Seoul, Korea \\ ${ }^{3}$ Department of Anatomy, College of Medicine, Kyunghee University, Hoeki-Dong 1, Dongdaemum-Ku, Seoul, Korea
}

(Received 19 April 2002 - Revised 30 September 2002 - Accepted 31 October 2002)

\begin{abstract}
The present study was designed to define how dietary fat type regulates body adiposity in dietary obesity-susceptible (DOS) Sprague-Dawley (SD) rats. Eighty-three SD rats received a purified diet containing $50 \mathrm{~g}$ maize oil (MO)/kg for 3 weeks and then thirty-nine of the rats, designated as the DOS rats, were allotted to diets containing $160 \mathrm{~g}$ MO (DOS-MO), beef tallow (DOS-BT) or fish oil (DOS-FO)/kg for 9 weeks. As a result of the experiment, the DOS-FO rats had significantly $(P<0 \cdot 05)$ reduced weight gain and abdominal and epididymal fat-pad mass than the DOS-MO and DOS-BT rats. Serum leptin level was also significantly $(P<0.05)$ lower in the DOS-FO rats; however, hypothalamic leptin receptor (a and b) mRNA and neuropeptide $\mathrm{Y}$ expressions were not altered by dietary fat sources. A lower acetyl-CoA carboxylase mRNA expression in the liver was observed in the DOS-FO group, whereas hepatic peroxisome proliferator-activated receptor- $\gamma$ mRNA and protein expressions were markedly elevated in the DOS-FO group compared with those in the other groups. We did not observe differences in acetyl-CoA carboxylase and peroxisome proliferator-activated receptor- $\gamma$ expressions in epididymal fat of the DOS rats consuming MO, BT or FO. It is concluded from our present observations that dietary fat type, especially that rich in FO, plays a potential role in down-regulation of adiposity by altering hepatic lipogenic genes, rather than feeding behaviour, in the DOS-SD rats.
\end{abstract}

Fat type: Leptin: Hypothalamic leptin receptor: Neuropeptide Y: Acetyl carboxylase CoA: Peroxisome proliferator-activated receptor- $\gamma$

There has been a considerable interest in the role of dietary fat type in the development of adiposity. However, the mechanisms by which dietary fat composition modulates body adiposity are still not conclusive, as several contradictory studies exist. It has been demonstrated that dietary fat type could have different regulatory effects on body-fat accumulation, adipogenesis and fat oxidation, although the development of adiposity depends in part on the strain, sex and age of animals (West \& York, 1998; Jump \& Clarke, 1999). However, the reported effect of dietary fat type, supplied by either polyunsaturated fatty acids (PUFA) or saturated fatty acids, on body weight, adipogenesis or lipolysis in rats varies (Awad et al. 1990; Hill et al. 1992;
Cha \& Jones, 1998). There is a lack of evidence on the responses of dietary $n-3$ and $n-6$ fatty acids to serum leptin level and leptin signalling pathway, although dietary PUFA can influence the composition of cellular membrane lipids and transmembrane receptor activities (Heshka \& Jones, 2001). Moreover, dietary composition of PUFA varies significantly with respect to its action on adiposity, even though both $n-3$ and $n-6$ PUFA appear to regulate fat synthesis and subsequent fat accumulation in numerous studies (Sessler \& Ntambi, 1998; Clarke, 2000). Thus, the goal of the present study was to investigate how dietary fatty acid composition modulates central and peripheral metabolic processes to regulate body adiposity.

\footnotetext{
Abbreviations: ACC, acetyl-CoA carboxylase; BT, beef tallow; DOS, dietary obesity-susceptible; FO, fish oil; MO, maize oil; NPY, neuropeptide Y; Ob-R, hypothalamic leptin receptor; $\operatorname{PPAR} \gamma$, peroxisome proliferator-activated receptor- $\gamma$; SD, Sprague-Dawley.

* Corresponding author: Dr InSurk Jang, fax +82 55751 3267, email isjang@jinju.ac.kr
} 
Leptin, the circulating $16 \mathrm{kDa}$ hormone secreted from adipocytes, is believed to regulate food intake and body weight via the hypothalamic leptin receptor (OB-R) and subsequently affects neuropeptide Y (NPY; Spiegelman \& Flier, 1996). Obese animals had higher serum leptin levels compared with normal-weight animals, suggesting that leptin level could be an index of adiposity in animals (Caro et al. 1996). However, it has also been suggested that dietary fat type, independent of body-fat mass, plays a crucial role in the plasma leptin level in dietary obesityinduced rodents (Cha \& Jones, 1998). As well as the central mechanism of leptin's obesity control, peripheral tissue acetyl-CoA carboxylase (ACC) and peroxisome proliferator-activated receptor- $\gamma$ (PPAR $\gamma$ ) are considered as the key adipogenic markers to influence body-fat mass (Clarke \& Jump, 1994). It is reasonable to investigate the regulatory action of dietary fat type on the adipogenic genes, since ACC and PPAR $\gamma$ are directly modulated by dietary substrate in the liver and adipocytes (Jump \& Clarke, 1999).

The discrepancy between dietary fat type and body-fat accumulation in many studies may be partly due to the genetic background of experimental animals. Therefore, care must be taken to consider the physiological relevance of the rodent models when we evaluate the effect of dietary fat type on the development adiposity. Among various animal models, Sprague-Dawley (SD) rats are able to reveal accurately the mechanisms that are applicable to polygenic animal obesity, because one-half of SD rats appear to develop obesity when fed diets moderately high in energy and fat (Lauterio et al. 1994).

In an effort to minimize genetic variability in dietary obesity-susceptibility (DOS), therefore, the present study was undertaken with the selected DOS-SD rats as a model animal to investigate the effect of dietary fat type including maize oil (MO), beef tallow (BT) and fish oil (FO) as a sole fat source on serum leptin, hypothalamic OB-R and neuropeptide Y (NPY), and peripheral ACC and PPAR $y$ expressions.

\section{Methods}

\section{Experimental animals, diet and procedures}

Male SD rats (Charles River, Atsugi, Japan) were maintained in polycarbonate cages under barrier-system-regulated temperature $\left(23 \pm 2^{\circ} \mathrm{C}\right)$, humidity $(50 \pm 10 \%)$ and light-dark cycle conditions. Eighty-three rats, aged 6 weeks and weighing $160-200 \mathrm{~g}$, received a purified diet containing $50 \mathrm{~g}$ $\mathrm{MO} / \mathrm{kg}$ for 3 weeks; the SD rats were then divided into two categories (higher weight-gainer, lower weight-gainer) on the basis of body-weight gain. Then, the heaviest rats ( $n$ 39, aged 9 weeks) in the higher-weight-gain group were designated as DOS-SD rats. The remaining forty-four rats were not used for the present study. These DOS-SD rats were allotted to the DOS-MO (160 g MO/kg), DOS-BT (160 g $\mathrm{BT} / \mathrm{kg}$ ) and DOS-FO (160 g FO/kg) groups by body weight and were given the purified diet individually and continuously ad libitum for another 9 weeks. Weekly body weight and daily food intake were measured throughout all studies. All animal experiments were approved by our laboratory animal care and use committee (accredited by AAALAC, Rockville, MA, USA) and were performed in compliance with our committee guidelines.

The diets differed only in fat type, as shown in Table 1. The primary differences among the three dietary fat types were higher levels of linoleic acid (n-6) and oleic acid $(n-9)$ in the MO diet, higher amounts of oleic acid and stearic acid in the BT diet and higher levels of eicosapentaenoic acid $(n-3)$ and docosahexaenoic acid $(n-3)$ in the FO diet. After the 9-week feeding trial, all rats were killed with anaesthetizing sodium pentobarbital $(100 \mathrm{mg} / \mathrm{kg})$, following 4-6h food deprivation at a fixed time between $14.00-16.00$ hours. Blood was drawn by heart puncture and serum was isolated. The liver, hypothalamus, abdominal fat and epididymal fat were collected, weighed and rapidly frozen in liquid $\mathrm{N}_{2}$. The tissues were stored at $-70^{\circ} \mathrm{C}$ until further assay.

\section{Serum biochemical analyses}

Serum leptin and insulin were assayed by Linco RIA insulin and leptin kits (Linco Research, St Charles, MO, USA) respectively, using a $\gamma$-counter $\left(\mathrm{COBRA}^{\mathrm{TM}}\right.$ II, Packard Bioscience, Meriden, CT, USA).

\section{Semiquantification of hypothalamic leptin receptor, acetyl- CoA carboxylase and peroxisome proliferator-activated receptor- $\gamma$ mRNA}

Total RNA was isolated from the hypothalamus, liver and epididymal fat by the methods of RNAsol B (Tel-Test, Friendswood, TX, USA). Briefly, $100 \mathrm{mg}$ tissue was removed from each organ and added to $1 \mathrm{ml}$ RNAsol solution. The samples were cut with scissors and homogenized using a glass-glass homogenizer. The lysate was transferred to microcentrifuge tube and added to $0 \cdot 1$ vol. chloroform to remove protein extract. The aqueous phase was separated by

Table 1. Purified diet formula and composition $(\mathrm{g} / \mathrm{kg})$

\begin{tabular}{lccc}
\hline $\begin{array}{l}\text { Treatment } \\
\text { item }\end{array}$ & DOS-MO & DOS-BT & DOS-FO \\
\hline Casein & 20 & 20 & 20 \\
MO oil & 16 & - & - \\
BT† & - & 16 & - \\
FO & - & - & 16 \\
Cellulose & 5 & 5 & 5 \\
Sucrose & 5 & 5 & 5 \\
Starch & 49 & 49 & 49 \\
DL-Methionine & 0.3 & 0.3 & 0.3 \\
Choline chloride & $0 \cdot 2$ & $0 \cdot 2$ & 0.2 \\
AlN-76 mineral mix & 3.5 & 3.5 & 3.5 \\
AIN-76 vitamin mix & $1 \cdot 0$ & 1.0 & 1.0 \\
Energy (kJ/kg) & 18,630 & 18,630 & 18,630 \\
Fat (\% energy) & 32.34 & $32 \cdot 34$ & $32 \cdot 34$ \\
\end{tabular}

DOS, dietary obesity-susceptible rats; MO, maize oil; BT, beef tallow; FO, fish oil.

* MO contains ( $\mathrm{g} / 100 \mathrm{~g}$ total fat): linoleic acid (18:2 $n-6) 57.4$, palmitic acid 13.3, oleic acid (18:1 $n$ 9) 26.0.

†BT contains ( $\mathrm{g} / 100 \mathrm{~g}$ total fat): oleic acid $41 \cdot 0$, palmitic acid $25 \cdot 1$, stearic acid $15 \cdot 6$.

ҒFO (Pronova Biocare, CO., Aalesund, Norway) contains: eicosapentaenoic acid (20:5 n-3) 18.0, docosahexaenoic acid (22:6, n-3) $12 \cdot 0$. 
centrifugation for $15 \mathrm{~min}$ at $15000 \mathrm{rpm}$. Total RNA was precipitated with the same volume of isopropanol and centrifuged for $15 \mathrm{~min}$ at $15000 \mathrm{rpm}$. The precipitated total RNA washed with ethyl alcohol $(750 \mathrm{ml} / \mathrm{l})$ was dried and diluted with diethyl pyrocarbonate-treated water. The concentration of isolated total mRNA was determined by spectrophotometer and confirmed on agarose $(1.0 \%)$ gel stained with ethidium bromide. Semi-quantification of mRNA using reverse transcription-polymerase chain reaction was performed to quantify mRNA of the leptin receptors, such as extracellular region common to all isoforms (OB-Ra, $814 \mathrm{bp}$ ) and intracellular domain of the long form (OB-Rb, $511 \mathrm{bp}), \mathrm{ACC}(580 \mathrm{bp}$ ) and PPAR $\gamma 2$ (306 bp). In brief, for synthesis of first strand cDNA, $5 \mu \mathrm{g}$ total RNA was incubated at $62^{\circ} \mathrm{C}$ for 10 min with $5 \mu \mathrm{g}$ oligo dT. The resulting solution was then continuously incubated at $42^{\circ} \mathrm{C}$ for $50 \mathrm{~min}$ in a reaction mixture containing $2.5 \mathrm{mM}-\mathrm{dNTP}$ and 200 units reverse transcriptase (BRL 18064-014; Gibco, Grassland, NY, USA). Then, 3.2 units RNAase H was treated to remove RNA hybridized with cDNA for $30 \mathrm{~min}$ at $37^{\circ} \mathrm{C}$. The amplification was performed for thirty cycles of denaturation at $94^{\circ} \mathrm{C}$ for $30 \mathrm{~s}$, annealing at $62^{\circ} \mathrm{C}$ for $30 \mathrm{~s}$ and extension at $72^{\circ} \mathrm{C}$ for $7 \mathrm{~min}$ with polymerase chain reaction system in a reaction mixture containing 10 pmol primer, $0.5 \mu \mathrm{g}$ cDNA, $2 \mathrm{~mm}-\mathrm{dNTP}$ and 1 unit Taq polymerase. The products were confirmed on agarose $(1.0 \%)$ gel stained with ethidium bromide. The cDNA primers to amplify each gene were as follows: 5'-TGGGTGTCTATCTCTGAAGTAAG$3^{\prime}$ and $5^{\prime}$-AATGGTGCTTTTGTTTGGCTG-3' for OB-Ra (gene bank accession no U52966), 5'-TATGGAAGGAGTTGGAAAACC-3' and 5'-TAACTGAGGGTTGACTCTGAC-3' for OB-Rb (gene bank accession no. U52966), 5'-GACAGGTTCAAGCTGAAGTC-3' and 5'-TCCTGAACTGTTCCAGAGCT-3' for ACC (gene bank accession no. JO3808), 5'- GCTCCAAGAATACCAAAGTG-3' and 5'-GCAAGGCACTTCTGAAACCG-3' for PPAR $\gamma 2$ (gene bank accession no. Y12882). The internal standard primers were $5^{\prime}$-GTGGGGCGCCCCAGGCACCAGGGC-3' and $5^{\prime}$-CTCCTTAATGTCACGCACGATTTC- $3^{\prime}$ for $\beta$-actin. We determined the number of cycles and kept the products within the exponential phase. The density of each product in agarose $(1.0 \%)$ gel electrophoresis containing ethidium bromide was quantified using a densitometer (Kodak EDAS 120; Kodak, New Haven, CT, USA). Levels of all mRNA were expressed as the value of signal intensity for genes relative to that for $\beta$-actin.

\section{Immunohistochemical assay of hypothalamic neuropeptide $Y$}

Immunohistochemical assays were performed as previously described (Huh et al. 1997). In brief, male SD rats ( $n 3)$ were perfused with freshly prepared paraformaldehyde $(40 \mathrm{ml} / \mathrm{l}$ $0 \cdot 1 \mathrm{M}-\mathrm{PBS}, \mathrm{pH} 7 \cdot 4)$. The removed brains were post-fixed in the same fixative overnight and continuously cryoprotected with sucrose solution ( $200 \mathrm{~g} / \mathrm{l} 50 \mathrm{~mm}-\mathrm{PBS}, \mathrm{pH} 7 \cdot 4)$ for $48 \mathrm{~h}$. Frozen sections of $40 \mu \mathrm{m}$ thickness in the coronal plane were stained for immunohistochemical detection of NPY using rabbit polyclonal antiserum (Incstar Corp., Stillwater, MN, USA). Free-floating sections were incubated for $72 \mathrm{~h}$ in PBS $\left(4^{\circ} \mathrm{C}\right)$ containing anti-NPY antiserum (1:2000 dilution), Triton $\mathrm{X}-100$ (3 ml/l), bovine serum albumin $(0.5 \mathrm{mg} / \mathrm{ml})$ and normal goat serum $(15 \mathrm{ml} / \mathrm{l})$. Sections were then incubated with goat antirabbit secondary antibodies (1:100; Vector, Burlingame, CA, USA) for $90 \mathrm{~min}$ and with avidin-biotin peroxidase complex (1:100; Vector) for $1 \mathrm{~h}$ at room temperature. Sections were reacted with $3,3^{\prime}$-diaminobenzidine tetrahydrochloride $(0.2 \mathrm{~g} / \mathrm{l})$ and $\mathrm{H}_{2} \mathrm{O}_{2}(0.1 \mathrm{ml} / \mathrm{l})$ for $3 \mathrm{~min}$.

\section{Western immunoblot assay of peroxisome proliferator-activated receptor- $\gamma$}

Briefly, protein extracts were prepared from the liver and epidydimal fat by polytron homogenization in an extraction buffer containing $40 \mathrm{~g} \mathrm{SDS} / \mathrm{l}$ and $10000 \mathrm{~g}$ centrifugation at $4^{\circ} \mathrm{C}$ for $30 \mathrm{~min}$. Protein concentration was assessed by bicinchoninic acid kit (Pierce, Rockford, IL, USA). Protein $(50 \mu \mathrm{g})$ was applied to SDS $(100 \mathrm{~g} / \mathrm{l})-\mathrm{PAGE}$ gel and the fractionated proteins were transferred to Hynond-P nitrocellulose membranes (Amersham, Piscataway, NJ, USA). Membranes were first incubated with antibody against polyclonal PPAR $\gamma$, which recognized only $\mathrm{N}$-terminal portion of PPAR $\gamma(1: 400$; Santa Cruz Biotech, Santa Cruz, CA, USA), for $1 \mathrm{~h}$ at $25^{\circ} \mathrm{C}$, washed immediately three times and then incubated with a secondary goat anti-mouse immunoglobulin $\mathrm{G}$ horseradish (Armoracia rusticana) peroxidase (1:1000; Amersham). The protein band was visualized by ECL Western blotting system (Amersham).

\section{Statistical analysis}

One-way ANOVA, followed by Tukey's multiple range test, was applied to analyse the results obtained from the three groups of the DOS rats fed MO, BT and FO. The level of probability for statistical difference was established at $P<0.05$.

\section{Results}

\section{Weight gain, feed intake and body-fat mass}

Body-weight gain and food intake in response to dietary fat type were monitored in all groups of the DOS-SD rats throughout the experimental period (Table 2, Fig. 1). When the effect of dietary fat type on weight gain after 9 weeks of feeding was examined, the DOS-FO rats $(266.5$ (SE 7.24) g) showed 12.3 and $11.3 \%$ lower $(P<0.05)$ weight-gain compared with the DOS-MO (299.3 (SE 8.41) g) and DOS-BT (296.7 (SE 7.23) g) groups fed MO and BT respectively (Table 2 ). However, body weight and mean daily food intake on a cumulative and weekly basis were not statistically different among the three dietary groups (Table 2, Fig. 1). Fig. 2 shows changes in abdominal and epididymal fat-mass obtained from the DOS-SD rats fed MO, BT and FO. Total abdominal fat-pad weights were 31.5 and $25.1 \%$ lower $(P<0.05)$ in the DOS-FO rats $(6.86$ $(\mathrm{SE} 0 \cdot 27) \mathrm{g})$ compared with the DOS-MO $(9.02(\mathrm{SE} 0.53) \mathrm{g})$ and the DOS-BT $(8.58(\mathrm{SE} 0 \cdot 34) \mathrm{g})$ rats respectively. Total epididymal fat-pad weights were also 61.2 and $44.5 \%$ decreased in the DOS-FO group (7.38 (SE 0.43) g) compared with the DOS-MO (11.90 (SE 0.37)g) and DOS-BT 
Table 2. Effect of dietary fat type on body weight, weight gain and food intake over entire period from the dietary-obesity susceptible (DOS)-Sprague-Dawley rats fed the diets containing $160 \mathrm{~g}$ maize oil (DOS-MO), beef tallow (DOS-BT) or fish oil (DOS-FO)*

(Mean values with their standard errors for thirteen rats per group)

\begin{tabular}{|c|c|c|c|c|c|c|c|c|c|c|}
\hline & \multicolumn{2}{|c|}{$\begin{array}{c}\text { Initial } \\
\text { weight (g) }\end{array}$} & \multicolumn{2}{|c|}{$\begin{array}{c}\text { Final } \\
\text { weight }(g)\end{array}$} & \multicolumn{2}{|c|}{$\begin{array}{l}\text { Weight gain over } \\
\text { entire period }(\mathrm{g})\end{array}$} & \multicolumn{2}{|c|}{$\begin{array}{l}\text { Daily food intake } \\
\text { over entire } \\
\text { period }(\mathrm{g} / \mathrm{d})\end{array}$} & \multicolumn{2}{|c|}{$\begin{array}{c}\text { Cumulative food } \\
\text { intake over entire } \\
\text { period ( } g / 9 \text { weeks) }\end{array}$} \\
\hline & Mean & SEM & Mean & SEM & Mean & SEM & Mean & SEM & Mean & SEM \\
\hline DOS-MO & 314.03 & 5.48 & $613 \cdot 33$ & $15 \cdot 51$ & $299 \cdot 30$ & $8 \cdot 41^{a}$ & $23 \cdot 25$ & 0.39 & 1464.58 & $24 \cdot 34$ \\
\hline DOS-BT & $313 \cdot 80$ & $5 \cdot 29$ & $610 \cdot 50$ & $10 \cdot 83$ & $296 \cdot 70$ & $7 \cdot 23^{a}$ & $23 \cdot 34$ & 0.30 & $1470 \cdot 60$ & $16 \cdot 17$ \\
\hline DOS-FO & $311 \cdot 19$ & $5 \cdot 37$ & 577.69 & $7 \cdot 74$ & 266.50 & $7 \cdot 24^{b}$ & $22 \cdot 85$ & 0.22 & $1439 \cdot 30$ & $13 \cdot 82$ \\
\hline
\end{tabular}

${ }^{a, b}$ Mean values in the same column with unlike superscript letters were significantly different $(P<0.05)$.

${ }^{*}$ For details of diets and procedures, see p. 430.

$(12 \cdot 4(\mathrm{SE} 1 \cdot 01) \mathrm{g})$ rats respectively. When body-fat mass was expressed per $100 \mathrm{~g}$ body weight, the statistically significant differences remained $(P<0 \cdot 05)$. The decreased abdominal and epididymal fat deposits in the DOS-FO rats partly reflected a lower weight gain.

\section{Serum biochemical analyses}

The DOS-FO group showed a $29.6 \%$ lower $(P<0.05)$ circulating leptin level $(10.56(\mathrm{SE} 0.91) \mathrm{ng} / \mathrm{ml})$ in the absence of considerable change in insulin concentration compared with the DOS-MO group (18.14 (SE 1.51) ng/ml; Fig. 3). Moreover, the DOS-FO rats had a $45.7 \%$ decrease $(P<0.05)$ in serum leptin level with a significantly lower serum insulin $(-38 \%)$ in comparison with the DOS-BT rats $(17.03(\mathrm{SE} 1.58) \mathrm{ng} / \mathrm{ml})$.

\section{Expressions of hypothalamic leptin receptor, neuropeptide $Y$, acetyl-CoA carboxylase and peroxisome proliferator- activated receptor- $\gamma$}

To examine the possibility of altered regulation of leptin's signalling pathway in the hypothalamus in response to dietary fat type (a lower circulating leptin level by FO),

(A)

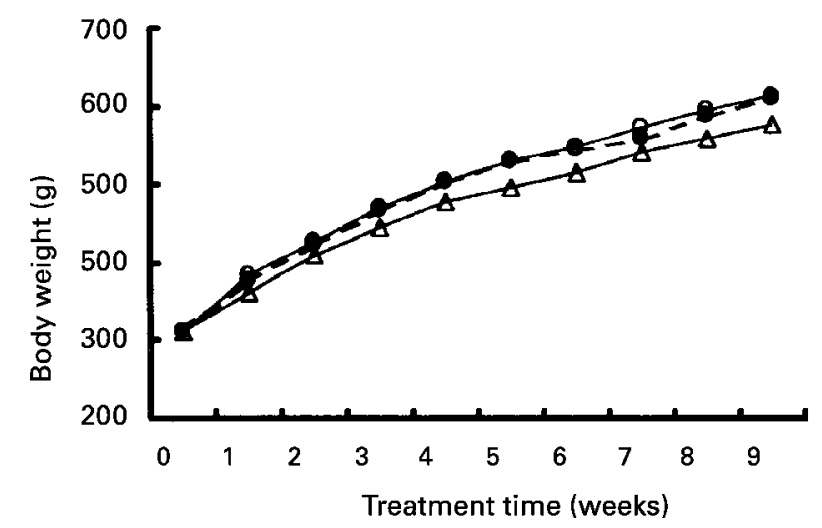

we investigated the expressions of hypothalamic OB-R mRNA and NPY by reverse transcription-polymerase chain reaction and immunohistochemical assay respectively (Figs 4 and 5). Dietary fat type did not noticeably affect hypothalamic OB-Ra and - Rb mRNA transcripts (Fig. 4). In particular, the DOS-FO group, having a remarkably low serum leptin level, showed similar hypothalamic OB-Ra and - Rb mRNA expressions compared with the DOS-MO and DOS-BT groups. When the response of NPY to dietary fat type in the arcuate and paraventricular nuclei of the hypothalamus was examined by immunohistochemical staining, the distributions of NPY expression in both nuclei were similar among treatments (Fig. 5). Therefore, dietary fatty acid composition (or lower serum leptin) did not significantly modulate hypothalamic OB-R and neuropeptide $\mathrm{Y}$ in the DOS-rats.

In order to examine the effect of fat type on peripheral adipogenesis in our DOS-SD model, ACC and PPAR $\gamma$ expressions in the liver and epididymal adipose tissue are compared in Figs 6 and 7. ACC is one of important key enzymes for synthesis of fatty acids in the liver and adipose tissue, and PPAR $\gamma$ appears to play a primary role in adipocyte differentiation and the storage of lipids. As a result, hepatic ACC mRNA expression was markedly $(P<0.05)$

(B)

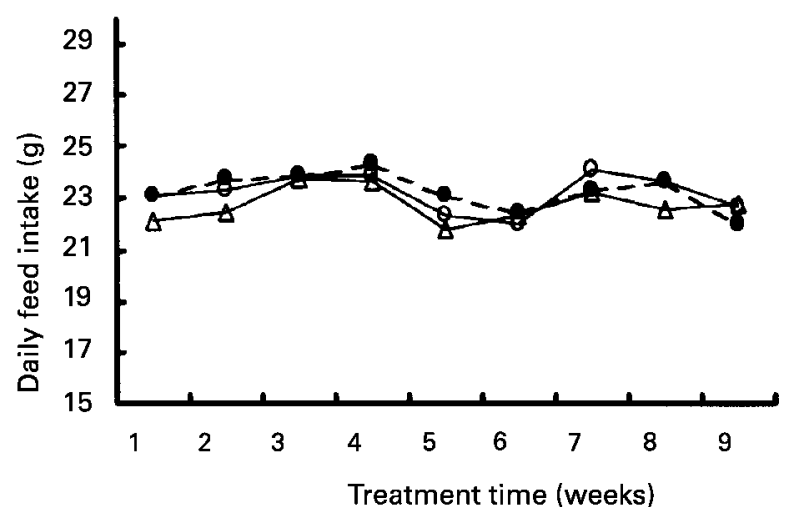

Fig. 1. Weekly changes in body weight (A) and daily feed intake (B) from dietary obesity-susceptible (DOS) Sprague-Dawley rats fed diets containing $160 \mathrm{~g}$ maize oil (DOS-MO, $\longrightarrow-\_$), beef tallow (DOS-BT, $--\mathbf{-}_{-}-$) or fish oil (DOS-FO, $\longrightarrow \triangle \longrightarrow$ )/kg for 9 weeks. For details of diets and procedures, see Table 1 and p. 430 . Values are means for thirteen rats per group. 


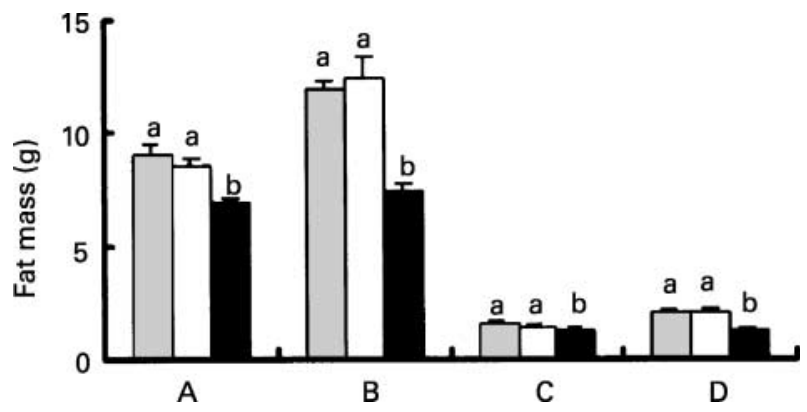

Fig. 2. Total (g; $A, B)$ and relative ( $g$ fat per $100 \mathrm{~g}$ body weight; $C, D$ ) abdominal $(A, C)$ and epididymal fat mass $(B, D)$ in dietary obesitysusceptible (DOS) Sprague-Dawley rats fed diets containing $160 \mathrm{~g}$ maize oil (DOS-MO, $\square$ ), beef tallow (DOS-BT, $\square$ ) or fish oil (DOS-FO, $\mathbf{a}) / \mathrm{kg}$ for 9 weeks. For details of diets and procedures, see Table 1 and p. 430. Values are means for five rats per group with standard errors shown by vertical bars. ${ }^{\mathrm{a}, \mathrm{b}}$ Mean values with unlike superscript letters were significantly different $(P<0.05)$.

lower in the DOS-FO as compared with that in the DOS$\mathrm{MO}$ and DOS-BT rats. In contrast, hepatic PPAR $\gamma$ mRNA expression was significantly $(P<0.05)$ higher in FO-fed DOS rats than in the other fat-fed DOS rats (Fig. 6). Western immunoblot assay of PPAR $\gamma$ also showed that hepatic PPAR $\gamma$ was noticeably greater in the DOS-FO rats (Fig. 7). However, we could not observe marked alterations in ACC and PPAR $\gamma$ mRNA expressions in the epididymal fat of the DOS-SD rats fed various fat sources including MO, BT and FO (Fig. 6). In addition, Western immunoblot of epididymal fat PPAR $\gamma$ protein was not markedly changed by dietary fat sources (Fig. 7).

\section{Discussion}

The responses of dietary fat type to the regulation of body adiposity are not consistent in the literature in which opposite results have sometimes been reported (Cha \& Jones, 1998; Loh et al. 1998; Reseland et al. 2001). The reason for this discrepancy may be due to dietary factors and to

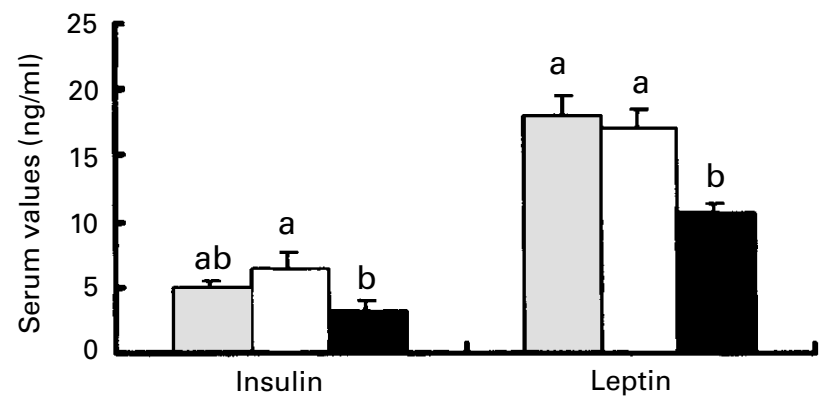

Fig. 3. Serum insulin and leptin levels in dietary obesity-susceptible (DOS) Sprague-Dawley rats fed diets containing $160 \mathrm{~g}$ maize oil (DOS-MO, $\square$ ), beef tallow (DOS-BT, $\square$ ) and fish oil (DOS-FO, $\mathbf{0}$ )/kg for 9 weeks. For details of diets and procedures, see Table 1 and p. 430. Values are means for ten rats per group with standard errors shown by vertical bars. a,b Mean values with unlike superscript letters were significantly different $(P<0.05)$.
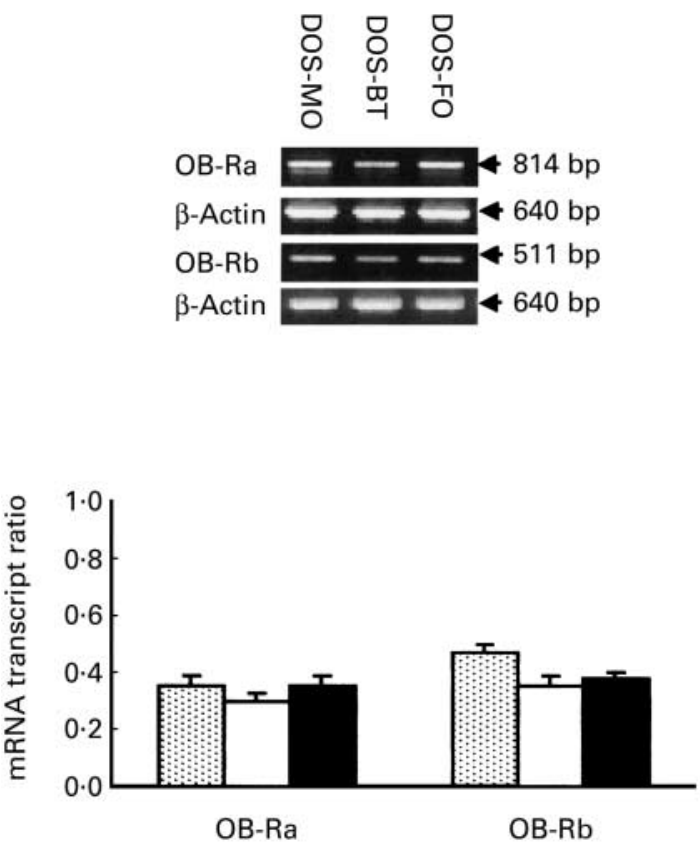

Fig. 4. Semi-quantification of mRNA expressions of hypothalamic leptin receptors (OB-Ra and $-\mathrm{Rb}$ ) in the hypothalamus of dietary obesity-susceptible (DOS) Sprague-Dawley rats fed diets containing $160 \mathrm{~g}$ maize oil (DOS-MO, 眷), beef tallow (DOS-BT, $\square$ ) or fish oil (DOS-FO, $\mathbf{\square}) / \mathrm{kg}$ for 9 weeks. Levels of all mRNA were expressed as the value of signal intensity for genes relative to that for $\beta$-actin. For details of diets and procedures, see Table 1 and p. 430. Values are means for five rats per group with standard errors shown by vertical bars.

the genetic backgrounds of the animals. To overcome these limitations, we used the DOS-SD rat to investigate the role of dietary fat type in the development of adiposity.

Dietary fat type, as well as amount of fat, are also thought to be important factors in determining body adiposity and adipogenesis (Takahashi \& Ide, 2000). However, several studies have reported that dietary fat supplied by either PUFA or saturated fatty acids did not markedly affect body weight, feed efficiency and lipogenesis in rats (Awad et al. 1990; Hill et al. 1992). SD rats fed FO and safflower oil had a markedly increased plasma leptin level compared with rats fed BT, despite smaller body-fat mass in the rats fed FO (Cha \& Jones, 1998). In our present study, in contrast to the studies mentioned earlier, the DOS-FO rats had a marked decrease in weight gain, fat-pad mass and serum leptin level compared with the DOS-MO and DOS-BT groups. It has been reported that a diet enriched with $n-3$ fatty acids decreased plasma leptin level and leptin mRNA in rat epididymal adipose tissue (Reseland et al. 2001). Several studies have indicated that a high-fat diet increases body fat, with a substantial increase in serum leptin level (Ahren et al. 1997; Bahceci et al. 1999). Circulating leptin level was is generally positively correlated with adiposity in human subjects and rodents (Frederich et al. 1995; Caro et al. 1996), although energy balance other than body-fat mass is likely to influence leptin production and secretion (Havel, 1998). It is thus reasonable to conclude that decreased body-fat deposition by feeding FO rich in $n-3$ fatty acids 


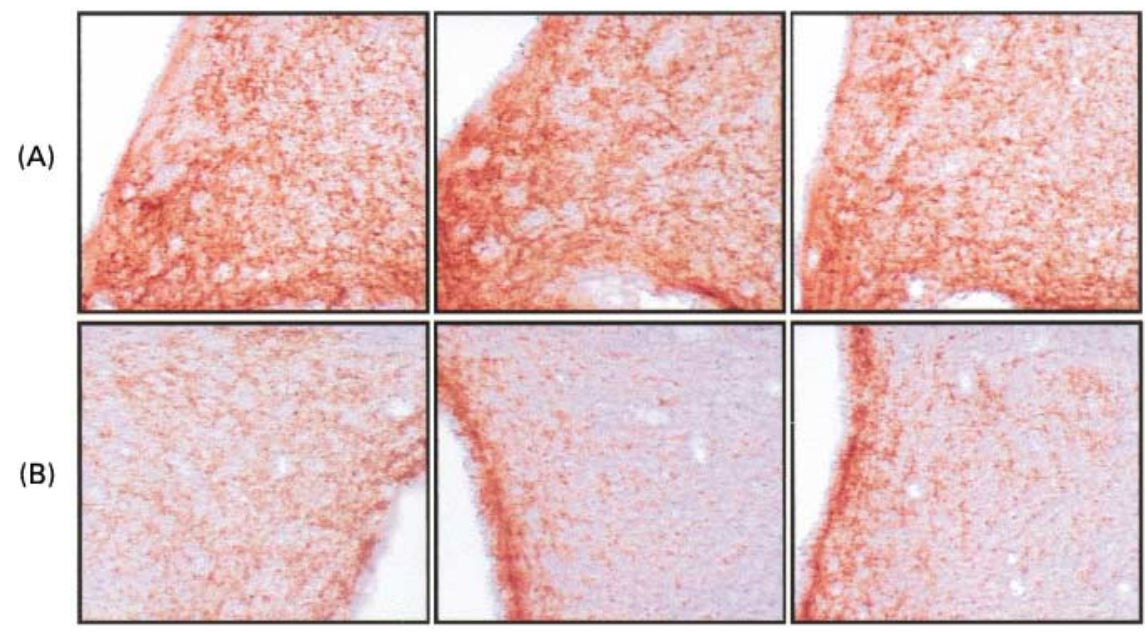

Fig. 5. Neuropeptide $\mathrm{Y}$ immunohistochemical assay in the hypothalamus (A, arcuate nucleus; $B$, paraventricular nucleus) of the dietary obesity-susceptible (DOS) Sprague-Dawley rats fed diets containing $160 \mathrm{~g}$ maize oil (DOS-MO), beef tallow (DOS-BT) or fish oil (DOS-FO)/kg as a major fat source. For details of diets and procedures, see Table 1 and p. 430.

reduces synthesis and secretion of leptin under normal physiological status in the DOS rats.

Leptin regulates food intake and body weight via hypothalamic OB-R (Flier \& Maratos-Flier, 1998) and consequently modulates NPY in the hypothalamus. Whether dietary fatty acid profiles would affect leptin's signalling pathway has rarely been investigated, although dietary

(A)
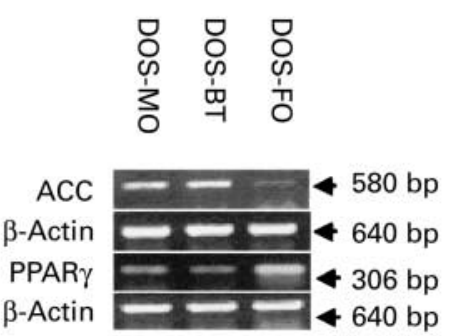

fatty acid composition is known to alter membrane fluidity in various tissues and to alter serum leptin levels, which could lead to changes in body-fat accumulation. We thus tried to determine whether dietary fat type and a lower circulating leptin level would affect hypothalamic OB-R and NPY in the DOS rats. In the present study, dietary $n-3$ and $n-6$ fatty acids did not affect the expression of

(B)
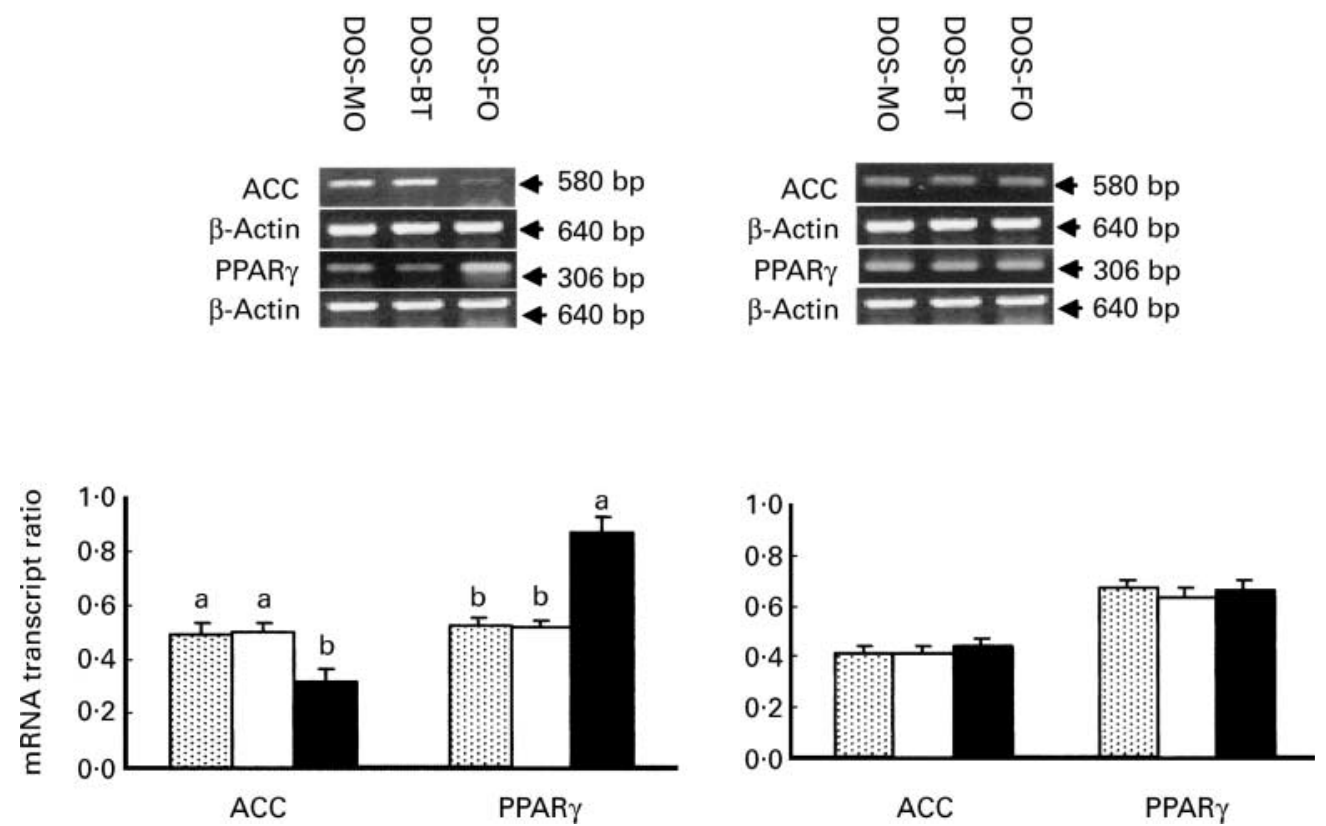

Fig. 6. Semi-quantification of mRNA expressions of acetyl-CoA carboxylase (ACC) and peroxisome proliferator-activated receptor- $\gamma$ (PPAR $\gamma$ ) in the liver (A) and epididymal fat (B) of dietary obesity-susceptible (DOS) Sprague-Dawley rats fed diets containing $160 \mathrm{~g}$ maize oil (DOS-MO, 圆), beef tallow (DOS-BT, $\square$ ) and fish oil (DOS-FO, $\square$ )/kg. For details of diets and procedures, see Table 1 and p. 430 . Levels of all mRNA were expressed as the value of signal intensity for genes relative to that for $\beta$-actin. Values are means for five rats per group with standard errors shown by vertical bars. ${ }^{a, b}$ Mean values with unlike superscript letters were significantly different among dietary groups $(P<0.05)$. 


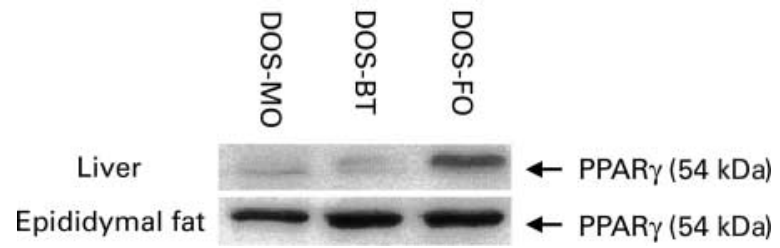

Fig. 7. Western blot of peroxisome proliferator-activated receptor- $\gamma$ (PPAR $\gamma$ ) in the liver and epididymal fat of the dietary obesitysusceptible (DOS) Sprague-Dawley rats fed diets containing $160 \mathrm{~g}$ maize oil (DOS-MO), beef tallow (DOS-BT) or fish oil (DOS-FO)/kg. For details of diets and procedures, see Table 1 and p. 430 .

hypothalamic OB-R and NPY, although the role of fat type in OB-R functions, such as leptin binding and transport in the hypothalamus, remains to be elucidated. In addition, a lower circulating leptin level in the DOS rats fed FO did not induce leptin action on hypothalamic OB-R mRNA; this is in agreement with a study suggesting that increased serum leptin was not enough to provoke up-regulation of OB-R expression (Lin et al. 2000). It is likely that circulating serum leptin in the DOS rats is not involved in the regulation of hypothalamic OB-R expression. It is a possible that the OB-R binding capability or signalling pathway of leptin in the hypothalamus of the DOS rats is impaired. Caro et al. (1996) reported that the high concentration of serum leptin in obesity was not reflected by a proportional increase in cerebrospinal fluid leptin in numerous animals. Burguera et al. (2000) also reported that leptin levels in cerebrospinal fluid were similar among lean Zucker, dietary-induced obese and genetically obese Zucker rats, although circulating plasma leptin levels were much higher in both obese rat groups. With DOS OsborneMendel rats, mRNA levels of OB-Ra and $-\mathrm{Rb}$ expression were not altered by a high-fat diet, but post-transcriptional expression of OB-R was markedly decreased by a high-fat diet (Madiehe et al. 2000). However, Wistar rats fed a high-fat diet $(340 \mathrm{~g} / \mathrm{kg})$ for 14 weeks showed up-regulation of OB-Ra mRNA in the blood-brain barrier, although plasma leptin level was not changed by a high-fat diet (Boado et al. 1998). The NPY regulation by dietary fatty acid composition has not been studied in detail so far, although NPY expression is known to be highly regulated by dietary fat amount and energy restriction. Several studies have demonstrated that dietary fat amount did not modulate compensatory NPY expression in DOS rats and mice compared with counterpart animals (Bergen et al. 1999; Lauterio et al.1999). Thus, it seems that DOS rats have NPY already expressed at a high level and this could lead to dysregulation of NPY expression in response to dietary fat (Levin \& Dunn-Meynell, 1997). Overall, dietary fatty acid composition did not promptly affect hypothalamic OB-R and NPY expression in the DOS animals after prolonged feeding periods.

As dietary fat type and a lower leptin level did not alter in hypothalamic OB-R and NPY expressions, we investigated changes in lipogenic gene expression in the liver and epididymal fat. Dietary fat type may regulate expression of key lipogenic enzymes such as ACC (Kim et al. 1999). PPAR $\gamma$, especially PPAR $\gamma 2$, has been shown to be induced by high dietary fat and PUFA, leading to changes in lipogenic gene expression and fatty acid metabolism in the liver and adipose tissue (Tugwood et al. 1996; Sessler \& Nambi, 1998). In the DOS-FO rats fed $160 \mathrm{~g} \mathrm{FO} / \mathrm{kg}$ there was a decrease in ACC mRNA expression in the liver, but not in the adipocyte. Such a reduced ACC mRNA expression could result in down-regulation of de novo lipogenesis in the liver and consequently reduced serum triacylglycerol (Clarke \& Jump, 1994; Harris et al. 1997). The mechanism by which n-3 fatty acids present in FO regulate lipogenic enzymes has been extensively studied. Several studies have indicated that $n-3$ fatty acids modulated lipogenic enzymes through both PPAR $\gamma$-dependent and -independent mechanisms of controlling adipogenesis (Clarke \& Jump 1994; Kliewer et al. 1997). Physiological concentrations of $n-3$ fatty acids have been associated directly with enhanced PPAR $\gamma$ to activate adipocyte differentiation, and increased PPAR $\alpha$ to induce peroxisomal $\beta$-oxidation (Reddy \& Mannaerts, 1994). Even if enhanced adipogenesis is commonly associated with obesity, increased adipogenesis by a greater PPAR $\gamma$ in response to dietary FO is strongly linked with a greater increase in insulin sensitivity and insulin receptors in peripheral tissues (Spiegelman \& Flier, 1996). These physiological phenomena lead to an increase in basic metabolic processes to prevent excessive adiposity, because a metabolic disorder of energy balance is directly involved in obesity (Spiegelman \& Flier, 1996). In particular, induction of the phosphorylated form of PPAR $\gamma$ has been considered as an anti-adipogenic factor acting by down-regulating transcriptional activity (Hu et al. 1996; Qian et al. 1998). However, feeding dietary MO to the DOS-SD rats did not induce changes in body-fat mass, leptin and hepatic lipogenic genes compared with feeding BT, although dietary fat enriched in $n-6$ fatty acids has been reported as a potent inhibitor of hepatic lipogenesis (Jump \& Clarke, 1999). We demonstrated that $n-3$ fatty acids had a more profound effect on the suppression of adipogenesis in the liver than $n-6$ fatty acids, as previously reported by Jump \& Clarke (1999).

Moreover, it was also reported that reduction of body-fat mass was partially due to an increase in hepatic lipid oxidation and decrease in adipocyte size in response to dietary $n$-3 fatty acids (Rustan et al. 1993). This result is in agreement with several studies, which demonstrated that $n$-3 fatty acids induced a higher $\beta$-oxidation rate and smaller fat cells, which eventually caused reductions in triacylglycerol and body-fat mass compared with the other types of fatty acids (Rustan et al. 1998; Halvorsen et al. 2001). In combining these observations with the present results, we could speculate that FO, rich in $n-3$ fatty acids, alters hepatic lipogenic genes and fatty acid oxidation, which in turn decrease fat accumulation and thus reduces circulating leptin level.

Taken together, dietary fatty acid composition and lower serum leptin level did not directly affect hypothalamic OB-R and NPY to regulate food intake and adiposity, whereas dietary fat type affected hepatic lipogenic genes in our DOS-SD rats. We conclude that, in our DOS-SD rat model, dietary $\mathrm{FO}$ has a crucial role in the regulation of body-fat mass via hepatic lipogenic gene modulation 
rather than leptin's central signalling pathway. Our present observations also suggest that dietary fat type is an important and feasible means to regulate body-fat stores in DOS animals. Much intensive work is still needed to define the role of dietary fatty acid profiles involved in leptin's biological actions on appetite, energy expenditure and nutrient absorption in obesity.

\section{Acknowledgements}

This research was carried out at the Korea FDA and supported by a grant from the National Institute of Toxicological Research, Korea FDA.

\section{References}

Ahren B, Mansson S, Gingerich RL \& Havel PJ (1997) Regulation of plasma leptin in mice: influence of age, high-fat diet and fasting. American Journal of Physiology 273, R113-R120.

Awad AB, Bernardis LL \& Fink CS (1990) Failure to demonstrate an effect of dietary fatty acid composition on body weight, body composition and parameters of lipid metabolism in mature rats. Journal of Nutrition 120, 1277-1282.

Bahceci M, Tuzcu A, Akkus M, Yaldiz M \& Ozbay A (1999) The effect of high-fat diet on the development of obesity and serum leptin level in rats. Eat Weight Disorder 4, 128-132.

Bergen HT, Mizuno T, Taylor J \& Mobbs CV (1999) Resistance to diet-induced obesity is associated with increased proopiomelanocortin mRNA and decreased neuropeptide Y mRNA in the hypothalamus. Brain Research 851, 198-203.

Boado RJ, Golden PL, Levin N \& Pardridge WM (1998) Upregulation of blood-brain barrier: short form leptin receptor gene products in rats fed a high fat diet. Journal of Neurochemistry 71, 1761-1764.

Burguera B, Couce ME, Curran GL, Jensen MD, Lloyd RV, Cleary MP \& Poduslo JF (2000) Obesity is associated with a decreased leptin transport across the blood-brain barrier in rats. Diabetes 49, 1219-1223.

Caro JF, Sinha MK, Kolaczynski JW, Zhang PL \& Considine RV (1996) Leptin: the tale of an obesity gene. Diabetes 45, 1455-1462.

Cha MC \& Jones PJ (1998) Dietary fat type and energy restriction interactively influence plasma leptin concentration in rats. Journal of Lipid Research 39, 1655-1660.

Clarke SD (2000) Polyunsaturated fatty acid regulation of gene transcription: a mechanism to improve energy balance and insulin resistance. British Journal of Nutrition 83, S59-S66.

Clarke SD \& Jump DB (1994) Dietary polyunsaturated fatty acid regulation of gene transcription. Annual Review of Nutrition 14, 83-98.

Flier JS \& Maratos-Flier E (1998) Obesity and the hypothalamus: novel peptides for new pathways. Cell 92, 437-440.

Frederich RC, Hamann A, Anderson B, Lollmann B, Lowell BB \& Flier JS (1995) Leptin levels reflect body lipid content in mice: evidence for diet-induced resistance to leptin action. Nature Medicine 1, 1311-1314.

Halvorsen B, Rustan AC, Madsen L, Reseland J, Berge RK, Sletnes P \& Christiansen EN (2001) Effect of long-chain monosaturated and $n-3$ fatty acids on fatty acid oxidation and lipid composition in rats. Annals Nutrition and Metabolism 45, 30-37.

Harris WS, Lu G, Rambjor GS, Walen AI, Ontko JA, Cheng Q \& Windsor SL (1997) Influence of $n-3$ fatty acid supplementation on the endogenous activities of plasma lipoprotein lipase. American Journal of Clinical Nutrition 66, 254-260.

Havel PJ (1998) Leptin production and action: Relevance to energy balance in humans. American Journal of Clinical Nutrition 67, 355-356.

Heshka JT \& Jones PJH (2001) A role for dietary fat in leptin receptor, OB-Rb, function. Life Sciences 69, 987-1003.

Hill JO, Lin D, Yakuba F \& Peters C (1992) Development of dietary obesity in rats: influence of amount and composition of dietary fat. International Journal of Obesity 16, 321-333.

Hu E, Kim JB, Sarraf P \& Spiegelman BM (1996) Inhibition of adipogenesis through MAP kinase-mediated phosphorylation of PPARgamma. Science 274, 2100-2103.

Huh Y, Kim C, Lee W, Kim J \& Ahn H (1997) Age-related changes in the neuropeptide $\mathrm{Y}$ and NADPH-diaphorase-positive neurons in the cerebral cortex and striatum of aged rats. Neuroscience Letters 223, 157-160.

Jump DB \& Clarke SD (1999) Regulation of gene expression by dietary fat. Annual Review of Nutrition 19, 63-90.

Lauterio TJ, Bond JP \& Ulman EA (1994) Development and characterization of a purified diet to identify obesity-susceptible and resistant rats populations. Journal of Nutrition 124, 2172-2178

Lauterio TJ, Davies MJ, DeAngelo M, Peyser M \& Lee J (1999) Neuropeptide Y expression and endogenous leptin concentration in a dietary model of obesity. Obesity Research 75, 498-505.

Levin BE \& Dunn-Meynell AM (1997) Dysregulation of arcuate nucleus preproneuropeptide Y mRNA in diet-induced obese rats. American Journal of Physiology 272, R1365-R1370.

Lin S, Storlien LH \& Huang X (2000) Leptin receptor, NPY, POMC mRNA expression in the diet-induced obese mouse brain. Brain Research 875, 89-95.

Loh MY, Flatt WP, Martin RJ \& Hausman DB (1998) Dietary fat type and level influence adipocity development in obese not but lean Zucker rats. Proceedings of the Society for Experimental Biology and Medicine 218, 38-44.

Kim HJ, Takahashi M \& Ezaki O (1999) Fish oil feeding decreases mature sterol regulatory element-binding protein 1 (SREBP-1) by down-regulation of SREBP-1c mRNA in mouse liver. Journal of Biological Chemistry 274, 25892-25898.

Kliewer SA, Sundseth SS, Jones SA, Brown PJ, Wisely GB, Koble CS, Devchand P, Wahli W, Willson TM, Lenhard JM \& Lehmann JM (1997) Fatty acid and eicosanoids regulate gene expression through direct interactions with peroxisome proliferator-activated receptors $\alpha$ and $\gamma$. Proceedings of the National Academy of Sciences of the United States of America 94, 4318-4323.

Madiehe AM, Schaffhauser AO, Braymer DH, Bray GA \& York DA (2000) Differential expression of leptin receptor in high- and low-fat-fed Osborne-Mendel and S5B/P1 rats. Obesity Research 8, 467-474.

Qian H, Hausman GJ, Compton MM, Azain MJ, Hartzell DL \& Baile CA (1998) Leptin regulation of peroxisome proliferator-activated receptor- $\gamma$, tumor necrosis factor and uncoupling protein-2 expression in adipose tissues. Biochemical and Biophysical Research Communications 246, 660-667.

Reddy JK \& Mannaerts GP (1994) Peroxisomal lipid metabolism. Annual Review of Nutrition 14, 343-370.

Reseland JE, Haugen F, Hollung K, Solvoll K, Halvorsen B, Brude IR, Nenseter MS, Christiansen EN \& Drevon CA (2001) Reduction of leptin gene expression by dietary polyunsaturated fatty acids. Journal of Lipid Research 42, $743-750$.

Rustan AC, Hustvedt BE \& Drevon CA (1993) Dietary supplementation of very long-chain $n-3$ fatty acids decreases 
whole body lipid utilization in the rat. Journal of Lipid Research 34, 1299-1309.

Rustan AC, Hustvedt BE \& Drevon CA (1998) Postprandial decrease in plasma unesterified fatty acids during $n-3$ fatty acid feeding is not caused by accumulation of fatty acids in adipose tissue. Biochimica et Biophysica Acta 1390, 245-257.

Sessler AM \& Ntambi JM (1998) Polyunsaturated fatty acid regulation of gene expression. Journal of Nutrition 128, 923-926.

Spiegelman BM \& Flier JS (1996) Adipogenesis and obesity; rounding out the big picture. Cell 87, 377-389.
Takahashi Y \& Ide T (2000) Dietary $n-3$ fatty acids affect mRNA level of brown adipose tissue uncoupling protein 1, and white adipose tissue leptin and glucose transporter 4 in the rats. British Journal of Nutrition 84, 175-184.

Tugwood JD, Aldridge TC, Lambe KG, MacDonald N \& Woodyatt NJ (1996) Peroxisome proliferator-activated receptors; structures and function. Annals of the New York Academic Sciences 804, 252-265.

West DB \& York B (1998) Dietary fat, genetic predisposition, and obesity: lessons from animal models. American Journal of Clinical Nutrition 67, 505S-512S. 